\author{
Alicja Jurgiel-Aleksander \\ Uniwersytet Gdański
}

\title{
Fenomenografia i jej poznawcze konsekwencje w świetle projektu na temat doświadczeń edukacyjnych dorosłych. Refleksja badacza
}

\author{
Phenomenography as a research method and its cognitive \\ consequences in the light of one research project on adult \\ learning experiences. Researcher's reflection
}

Streszczenie. Głównym celem niniejszego tekstu jest rekonstrukcja głównych założeń fenomoenografii jako metody stosowanej w badaniach edukacyjnych. Odnosząc się publikacji Ferenca Martona - twórcy tej metody - autorka stara się wyróżnić główne kwestie, na które warto zwrócić uwagę badaczy, którzy chcą realizować swoje projekty w tej właśnie perspektywie. Co więcej, odwołując się do własnych doświadczeń badawczych obejmujących problem uczenia się dorosłych, ujawnia refleksje na temat fenomenografii. Zdaniem autorki artykułu istnieje kilka poznawczych konsekwencji stosowania tej metody w projektach, które jednocześnie kształtują jej potencjał. Po pierwsze, w naturze fenomenografii nie jest dzielenie świata naszych doświadczeń na biały i czarny, ale raczej definiowanie jego znaczenia przez pryzmat rożnych odcieni doświadczanego zjawiska. Po drugie, różnica w doświadczaniu świata przez podmioty jest pochodną kultury, w której funkcjonujemy. Po trzecie, fenomenografia nie tylko rekonstruuje praktyki społeczne, ale jednocześnie pokazuje, że istnieje na nie społeczne zapotrzebowanie.

Słowa kluczowe: fenomenografia; uczenie się dorosłych; doświadczenia edukacyjne.

Summary. The main aim of this article is to reconstruct the basic features of phenomenography as the methodological approach and method of gathering data in educational research. Referring to publications of Ferec Marton, the main creator of this method, the author tries to name basic issues important for researchers who want to undertake phenomenography in their projects. What is more she unveils her experiences connected with her own research on adult learning conducted in the phenomenography perspective. In her opinion, there are very important cognitive consequences of applying this method in projects which create its potential at the same time. The first one is that phenomenography does not divide the world 
of our experiences into black and white; it feeds the shadows and allows to define the world through the prism of different colours of one phenomenon. The second feature is showing that the distinction of experiences is rooted in the world of culture in which we exist. The third is that thanks to this method a researcher does not only reconstruct social practices but they can show that a society needs these practices and cannot even imagine that their everyday life could be changed.

Key words: phenomenography; adult learning; educational experiences.

\section{Wprowadzenie}

Celem niniejszego tekstu jest próba opisu fenomenografii jako podejścia metodologicznego, wykorzystywanego w badaniach nad edukacją na szwedzkim gruncie od wielu lat. W Polsce spopularyzowanych w latach 90., dzięki projektom europejskim zorientowanym na rekonstruowanie percepcji wiedzy w dydaktyce akademickiej w perspektywie porównawczej (zob. Dahlgren $\mathrm{i}$ inni 2005), ale także $\mathrm{z}$ powodzeniem realizowanych $\mathrm{w}$ indywidualnych badaniach takich autorów jak: Lucyna Kopciewicz (2007), która identyfikowała opresyjne mechanizmy konstruowania rodzaju tkwiące w kulturze, Astrid. Męczkowska (2002), która próbowała pokazać relacje między koncepcją wymagań szkolnych a niekompetencją krytycznego myślenia ucznia, czy Marzenna Nowicka (2010), która śledziła uważnie mechanizmy socjalizacji w szkole.

Fenomenografia podobnie jak inne metodologie typu interpretatywnego traktuje uczenie się jako praktykę kulturową i społeczną. W andragogice to przekonanie ma kapitalne znaczenie, ponieważ już na samym początku pozwala widzieć uczenie się nie jako wyłącznie akt czystego poznania, iluminacji czy cechę organizmu wpisaną w standard jego zachowań - jak to zwykle przyzwyczailiśmy się traktować - a przeciwnie jako fenomen społecznie i kulturowo wytwarzany. Parafrazując krytycznego badacza Stephen Brookfielda (2010), można by powiedzieć, iż to podejście oznacza, że sposób, w jaki się uczysz, oznacza sposób, w jaki żyjesz.

\section{Co wiemy o fenomenografii?}

Fenomenografia jako metoda postępowania badawczego została rozwinięta w latach 70. w ośrodku studiów na edukacją na uniwersytecie w Goeteborgu przez badaczy związanych z Martonem. W dosłownym tłumaczeniu fe- 
nomenografia oznacza opis rzeczy, zjawisk, które ujawniają nam się w bezpośrednim doświadczeniu. Marton (1997) w swoich publikacjach pisze, że fenomenografia to empiryczne studium ograniczonej liczby jakościowo różnych sposobów rozumienia, postrzegania, konceptualizowania, doświadczania zjawisk otaczającego świata. Rezultatem poznawczym fenomenografii jest „rysowanie” przez badaczy mapy ujawniającej różne sposoby doświadczania zjawisk przez badanych (Szkudlarek 1997). Ich odczytanie i konceptualizacja ma swoje konsekwencje praktyczne. Zarówno twórcy metody, jak i jego współpracownikom zależało bowiem na ulepszeniu procesu kształcenia w uniwersytecie, dlatego pytania poznawcze, które wtedy sformułowali, miały następującą postać: Co to znaczy, że jedni ludzie są lepsi a drudzy gorsi w uczeniu się? Dlaczego jedni radzą sobie lepiej od innych? Odczytanie rozmaitych sposobów rozumienia (doświadczania) uczenia się przez studentów stanowiło cel tamtego i późniejszych badań fenomenograficznych. Można więc powiedzieć, że geneza tych badań ma wyraźnie edukacyjny i praktyczny kontekst. Badaczom zależało bowiem na opisie doświadczeń uczenia się studentów po to, by proces studiowania zmienić, ulepszyć, zmodyfikować, ale nie tylko w wymiarze organizacyjnym i logistycznym, ale przede wszystkim koncepcyjnym.

W opisywanej tu konwencji badacze używają zamiennie słów: doświadczanie, postrzeganie, rozumienie i nie jest to przypadkowe. Wynika to z natury samego przedmiotu badania, którym są jakościowo różne sposoby uczestnictwa człowieka w świecie, tym samym rozumienia świata. To oznacza, że fenomenografowie traktują doświadczenie jako wpisane w charakter bycia człowieka w świecie. Ich zdaniem człowiek jest częścią rzeczywistości, w której funkcjonuje i którą jednocześnie kreuje. Sposób, w jaki doświadczenie jest opisywane, nie należy do świata zjawisk fizycznych czy psychologicznych, a jest raczej rodzajem indywidualnej relacji pomiędzy człowiekiem a zjawiskiem. Jak twierdzi Marton (1997), nie jesteśmy świadomi tego samego w tym samym czasie, a nawet gdyby tak było, to nie doświadczamy zjawisk w taki sam sposób. Sam Marton (1997) zauważa jednak, że sposób doświadczania zjawiska czy sytuacji dotyczy jednocześnie sposobu „wytwarzania” znaczenia w konkretnym czasie i przestrzeni w określonej kulturze. Dlatego dopiero ujawnione przez badaczy koncepcje znaczeń nadane zjawisku stanowią rezultat prowadzonych studiów nad rodzajem doświadczeń badanych i sposobem ich konceptualizacji.

Dla fenomenografów struktura i znaczenie doświadczanego fenomenu może zostać odnaleziona przez badacza zarówno w jednym, jak i drugim. Istotne jest bowiem nie to, jaki świat jest, ale to, jaki świat jawi nam 
się w bezpośrednim doświadczeniu (zob. Richardson 1999). Dlatego pisząc o epistemologicznych korzeniach fenomenografii, sam Marton nie ukrywa, że zostały one skonstruowane ex post, a nie wyprowadzone bezpośrednio z fenomenologii. Dlatego niektórzy (zob. Fox 1983, Hasselegren i inni 1997) piszą, że fenomenografia jest tym, co badacz robi w trakcie tego badania, chcąc podkreślić praktyczny jej wymiar. Istotna różnica pomiędzy podejściem fenomenologicznym a fenomenograficznym leży w sposobie rozumienia celu badania i znaczenia świadomości w procesie poznania. Zdaniem Martona (1997) fenomenolodzy traktują rzeczywistość jako niezależną od świadomości, a wiedzę o świecie jako konstruowaną niezależnie od wcześniejszych doświadczeń. Dla fenomenografów nie ma innego świata jak tylko ten, którego doświadczamy, a który jednocześnie konstruowany jest w naszej świadomości. Dlatego zwolennicy pierwszego podejścia, jak wyjaśnia autor, będą poszukiwali pojedynczej istoty zjawiska, a zwolennicy drugiego jakościowo różnych aspektów tego samego fenomenu.

Przedmiotem analiz fenomenograficznych jest tekst, będący rekonstrukcją wypowiedzi zgromadzonych metodą semistrukturyzowanego wywiadu indywidualnego lub grupowego. W czasie przeprowadzania wywiadu należy mieć na względzie, że odwołujemy się do doświadczeń podmiotu w zakresie zjawisk, o których rozumienie pytamy. Dlatego formuła pytań fenomenograficznych w rozmowie ma postać: Czym jest dla ciebie dane zjawisko? Co to znaczy według ciebie? Czy możesz to wyjaśnić? Jak do tego zjawiska doszedłeś? Co ten problem znaczy dla Ciebie? Prośba badacza o objaśnianie, uzupełnianie, rozwinięcie wypowiedzi w trakcie nagrywania rozmowy jest nieodłącznym elementem stosowanej procedury.

Kluczową dla przedstawiania rezultatów badania fenomenograficznego jest koncepcja będąca fundamentalnym sposobem rozumienia fenomenu lub postrzegania przedmiotów w otaczającym świecie. Ten rodzaj opisu indywidualnego doświadczenia świata zaliczany jest do analiz drugiego rzędu, ponieważ ich celem jest próba odpowiedzi na pytanie: jaki świat jawi się badanemu w bezpośrednim doświadczeniu? Dlatego ważne są nie tylko stwierdzone przez respondenta fakty, ale sposób ich uzasadnienia. Założeniem fenomenografii jest to, że potoczne opisy zjawisk przez badanych zaopatrzone są w rodzaj wiedzy niewidocznej, bo przez badanych nienazwanej. Dopiero rolą badacza jest konceptualizacja wiedzy o sposobach doświadczania zjawiska przez podmioty w postaci kategorii opisu. Ich tworzenie ma niezwykle realistyczny charakter, dlatego Marton (zob. Marton, Booth 1997, Marton 1986) często sygnalizuje w swoich pracach, że rodzaj stosowanej tu strategii przypomina pracę botanika, który odkrywa nowe ga- 
tunki roślin, opisuje je i nazywa. To kategorie opisu tworzą tzw. przestrzeń wynikową. Sposób dochodzenia badacza do kategorii opisu wymaga zastosowania następującej procedury:

- zapoznanie się badaczy z tekstem wywiadów, kilkukrotne czytanie wypowiedzi z odwoływaniem się do nagranego materiału badawczego (zwłaszcza wtedy, gdy badacz nie wykonywał transkrypcji osobiście);

- kondensacja polegająca na wyselekcjonowaniu fragmentów rozmowy z tekstu wypowiedzi badanych, które dotyczą, opisywanego zjawiska; w znalezieniu kluczowych fragmentów wypowiedzi należy być ostrożnym, by nie nanosić własnych „przedzałożeń”, a rzeczywiście zrekonstruować to, co badany wniósł do dyskusji;

- porównywanie wyłonionych na etapie kondensacji fragmentów wypowiedzi w taki sposób, aby sprecyzować, jaki fenomen wnieśli do rozmowy badani oraz w jaki sposób jego aspekty są przez badanych doświadczane;

- grupowanie odpowiedzi na podstawie pojawiających się podobieństw i różnic;

- ustalanie kryterium (istoty) pojawiających się na wcześniejszym etapie podobieństw i różnic;

- nazywanie kategorii w taki sposób, aby nazwa odpowiadała domenie opisywanego zjawiska oraz jego różnorodnych sposobów doświadczania (rozumienia) przez podmioty;

- odniesienie wyłonionych kategorii opisu do teorii i perspektyw meta, dotyczących analizowanego zjawiska (zob. Franke i Dahlgren 1996, Eklund-Myrskong 1998).

Koncepcja opisywanego zjawiska konstruowana jest w wyniku nasycenia kategorii fragmentami wypowiedzi różnych respondentów, ale może się też zdarzyć, że wypowiedź jednej osoby może zostać rozerwana na fragmenty i trafić do kilku odmiennych znaczeniowo kategorii opisu. Dlatego mówi się, że kategoria ma charakter jednostkowy i kolektywny zarazem i z tego powodu jej tworzenie nie jest wolne od komplikacji. Na poziomie poszukiwania różnic i podobieństw stanowisk respondentów w danej kwestii badacz musi zdecydować czy fragment wypowiedzi jest odzwierciedleniem rozmaitych ekspresji tej samej koncepcji, czy różnych koncepcji. To oznacza, że badacz sam ustala ideę organizującą koncepcję, a następnie musi uprawomocnić ów wybór (Richardson 1999).

Na podstawie powyższych założeń i wskazówek zrealizowałam projekt, którego celem była fenomenograficzna rekonstrukcja mechanizmu kształtowania doświadczeń edukacyjnych w ciągu życia przez dorosłych, którzy na pewnym etapie swojego dorosłego życia stali się studentami. Warto za- 
znaczyć, że nie jest moim celem w tym miejscu dokładne relacjonowanie jego wyników, tym bardziej że szczegółowy raport z tych badań zostały już opublikowany (Jurgiel-Aleksander 2008, 2013, 2015). Odwołam się jedynie do wybranych przykładów, aby pokazać, jakich konsekwencji poznawczych trzeba być świadomym, realizując badania tą właśnie drogą. I dlaczego warto zapytać siebie jako badacza/badaczkę czy jestem gotów/gotowa zmierzyć się z tak niełatwą do analizy materią, której rezultatem poznawczym jest wiedza o sposobach doświadczania zjawisk ujawniona w postaci koncepcji, których charakter może okazać się w takim samym stopniu trwały co tymczasowy.

\section{Koncepcje doświadczeń edukacyjnych jako przejawy rozumienia uczenia się $w$ ujęciu dorosłych. Refleksja nad własną praktyką badawczą}

Analizując edukacyjne ścieżki w biografiach dorosłych ${ }^{1}$ - którzy odgrywają kilka ról jednocześnie, łącząc pracę zawodową ze studiami i obowiązkami rodzicielskimi -zadawałam sobie pytanie, jaki jest mechanizm konstruowania przez nich doświadczeń, które w ich ujęciu są uczące i kiedy mają one, ich zdaniem, edukacyjny potencjał. Zgodnie z procedurą fenomenograficzną było to pytanie o koncepcje doświadczenia edukacyjnego. Jego konstrukcja została ujawniona dzięki zastosowanej i opisanej powyżej procedurze polegającej na: kondensowaniu tekstu wypowiedzi pochodzących z 24 pogłębionych wywiadów na temat własnego uczenia się i jego znaczenia w życiu, porównywaniu pól tematycznych, ujawnieniu różnic i podobieństw między pomysłami w uzasadnieniach badanych, wyłonieniu kategorii opisu doświadczenia edukacyjnego. W rezultacie analiza pokazała zaledwie trzy sposoby rozumienia tego, czym jest doświadczenie, traktowane przez badanych jako edukacyjne. I tak:

- doświadczenie edukacyjne traktowane jest jako rezultat przebywania w instytucji kształcącej oraz jako rezultat absorbcji wiedzy (A);

1 Badaniu podlegało 24 biografii osób między 21 a 40 rokiem życia, ich uczący potencjał wynikał zarówno z tego, że narracja pokazywała odgrywanie kilku ról jednocześnie, jak i z tego, że przeszli oni drogę przez system kształcenia dla dorosłych - od szkoły zawodowej przez liceum dla dorosłych i studia niestacjonarne w trybie zaocznym. Warto wspomnieć, że w swoich rodzinach było to pierwsze pokolenie uczące się w szkole średniej z maturą i studiujące w szkole wyższej. Wyniki badań dotyczące ich doświadczeń edukacyjnych i uczenia się opublikowałam w tekstach: Jurgiel-Aleksander 2011; 2013; 2014; 2015. 
- doświadczenie edukacyjne rozumiane jest jako konsekwencja niedoświadczania edukacji adekwatnej do oczekiwań badanych na każdym etapie ich kształcenia (B);

- doświadczenie edukacyjne postrzegane jest jako rezultat procesu wymiany zasobów (C).

\section{Doświadczenie edukacyjne jako rezultat przebywania $w$ instytucji kształcącej i jako rezultat absorbcji wiedzy (A)}

Kryterium opisu tej kategorii jest umiejętność znalezienia się w roli ucznia lub w roli studenta, których to ról się nie różnicuje. Przyswojenie roli ucznia lub studenta stanowi o treści wytworzenia tej kategorii opisu, natomiast aspekt formalny, oddający to jak badani rozumieją, czym jest dla nich doświadczenie edukacyjne - wytworzony został w ich świadomości przez:

a) wyraźny podział na dwa odrębne środowiska uczenia się, tj. szkolne i pozaszkolne jako odrębne światy (niezależne od siebie i nieprzystające do siebie), gdzie to świat szkolnej edukacji jest właściwym polem budowania doświadczeń edukacyjnych, bo mających znaczenie dla kariery i statusu:

Kiedy poszłam do liceum dla dorosłych najbliżsi mi kibicowali, ale tez byli sceptyczni. Teraz kiedy jestem na studiach już widzą, że można wszystko jeśli tylko chcesz. Dużo czytam, przyswajam wiedzę w małych lub większych dawkach. Nie wyobrażam sobie innego sposobu, jak chodzić na wykłady i robić to, co każą wykładowcy. W naukach społecznych jest tej wiedzy dużo i taka rozległa, ale trzeba to przyswoić. To tak jak biolog wie co to fotosynteza, to my musimy wiedzieć kto to Freud czy znać zaburzenia rozwoju człowieka. Śmieszy mnie ta cała dyskusja o uczeniu się w grupie. Niby od kogo mam się uczyć, od moich rówieśników, których rodzice tak jak moi nie mają wykształcenia?! To jakiś absurd! Jakie doświadczenia mam zdobywać w ten sposób skoro oni są tacy sami jak ja? Nawet mieszkamy na tym samym osiedlu, bo rodzice dostali przydział ze stoczni (Jurgiel-Aleksander, 2013).

b) traktowanie szkoły i uczelni jako instytucji kształcących nieróżniących się od siebie, jeśli chodzi o metody nauczania. Mamy tu do czynienia z wyraźnym ukierunkowaniem na dydaktykę trenowania i zapamiętywania jako zapewniającej sukces edukacyjny:

Gdyby tak pomyśleć, to przecież całe te studia opierają się na wykładach, czasem ciekawych, czasem nie. Ale nikt się tym nie przejmuje. To co tu jest skomplikowanego. Masz to wchłonąć i już! A potem ewentualnie się zastanowisz 
czy to potrzebne. Nie widzę w tym nic dziwnego. Taka jest szkoła, zawsze taka była. Miałam pretensje, że to nie moje, obce, dużo teorii. Ale trudno, musisz to jakoś wytrzymać. Siedzieć słuchać i wkuwać! (Jurgiel-Aleksander, 2013)

c) pełną identyfikację ze studiowaną dyscypliną i charakterem jej studiowania jako determinujących sposób uczenia się w ogóle, przekładający się na inne sfery życia:

Kiedy uczysz się systematycznie i przebywasz w szkole, to idzie jak z płatka. Tylko nie możesz niczego przekładać na potem. Tego nauczyła mnie mama i jakoś tak mam, że staram się wytrzymać. Jak sobie poukładasz, że psychologia wymaga pamięciowej obróbki to potem samo przychodzi. Najtrudniej jest przejść przez pierwszy rok, sama teoria, trudna, ale ciekawa. Mi jest łatwiej, bo mam za sobą kolegium dla pracowników socjalnych, wcześniej zawodówkę i liceum dla pracujących, więc mam wprawę w uczeniu się. Szkoła tego uczy, potem już tylko zapamiętujesz. (Jurgiel-Aleksander, 2013)

Rozumienie doświadczenia edukacyjnego jako rezultatu przebywania w instytucji kształcącej i jako absorbcji wiedzy niesie w sobie konceptualizacje uczenia się i wiedzy, ale także określa sposób doświadczania społecznego urządzenia świata. I choć uczenie się opisywane w kontekście przyrostu wiedzy w świecie i konieczności sprostania wymaganiom jako reakcja na jej ciągłą dezaktualizację, z pewnością nie jest nowym odkryciem, to sam sposób opisu jej nabywania jako wpisany w funkcjonujący typ kultury dydaktycznej, niepoddawany refleksji, a przyjmowany jako „oczywista droga poznania" pokazuje w rezultacie takie wobec niej oczekiwania. Ta kategoria opisu wskazuje na powszechną aprobatę dla widzenia w dydaktyce dorosłych głównie jej kompensacyjnej funkcji, to znaczy edukacji zredukowanej do wyrównania braków w formalnym wykształceniu, tym samym braków w wiedzy i umiejętnościach wskazanych jako standard dla danego poziomu kształcenia.

\section{Doświadczenie edukacyjne jako konsekwencja niedoświadczania edukacji adekwatnej do oczekiwań badanych na każdym etapie ich kształcenia (B)}

Ta koncepcja doświadczenia edukacyjnego jest pochodną doświadczanej w biografii edukacji jako nieadekwatnej do świata, w którym dorośli żyli i żyją. Nieadekwatność dotychczasowej ścieżki edukacyjnej została zbu- 
dowana na: a) krytyce szkoły jako instytucji, która nie spełnia oczekiwań jej adresatów i wyrażona została w języku „, braków”, czyli zarzutów wobec tego, czego szkoła nie robi, a zdaniem badanych robić powinna, b) wskazaniu nowych miejsc uczenia się traktowanych jako źródła gotowych rozwiązań takich jak: Internet, miejsca pracy, koledzy.

Doświadczenie edukacyjne jako konsekwencja niedoświadczania edukacji adekwatnej do oczekiwań badanych na każdym etapie ich kształcenia w materiale badawczym pojawiała się w kontekście:

a) „odrealnionej” koncepcji kształcenia uprawianej w szkole i na uniwersytecie, osadzonej najpierw w charakterze nauczanych przedmiotów, później w charakterze studiowanej dyscypliny i obowiązującej dydaktyce zorientowanej na odtwarzanie treści kształcenia. Ten krytyczny sposób podejścia do kultury uczenia się i studiowania wynikający z tego, że zdaniem dorosłych szkoła wykluczyła ich z podejmowania wpływu na sposób uczenia się i studiowania daje o sobie znać wówczas, gdy w materiale badawczym mowa jest o sposobie prowadzenia zajęć dydaktycznych, o tym jak prowadzone są wykłady („nudne”, „bez przykładów z życia”, „podają nam przestarzałą wiedzę niemającą nic wspólnego z tym, co dzieje się za oknem"). Ale także wtedy, gdy badani budują obraz uczelni jako miejsca, którego głównym zadaniem w sferze kształtowania kompetencji powinno być przygotowanie do świata pracy:

W szkole nigdy nie rozumiałem, po co mi ta wiedza. Musiałem wkuć i już. Nikt mi nie pokazywał, do czego może się przydać. Mam wrażenie, że na studiach też! Od czasu do czasu ktoś sobie przypomniał podczas wykładu, że może jakieś przykłady by się przydały, choć starasz się przekładać sobie sam to, co mówią wykładowcy, na to, co ważne w twoim życiu. Ja to robiłem i teraz wiem, że to dobre doświadczenie, dzięki temu coś znaczysz. Ale za dużo po uczelni sobie nie obiecuję. (Jurgiel-Aleksander, 2013)

b) eksponowania znaczenia codzienności jako źródła praktycznego uczenia się, to znaczy jako źródła kształtowania umiejętności o „działaniowym" charakterze (w tym rozumieniu szkoła jest poza codziennością). Tutaj każde nowe środowisko uczenia się jest zastępczym wobec szkolnego, niespełniającego kryteriów nowoczesności i realnym w sensie rodzaju kształtowanych umiejętności potrzebnych dorosłym tu i teraz:

Od jakiegoś czasu machnąłem ręką na szkołę. Wiem, że papier jest potrzebny, ale nie jest już nic wart. Kiedy otwierałem własną firmę, to się o tym przekonałem. To w codziennym życiu, kontaktach, rozmowach zdobywasz rze- 
czywiste kompetencje, a nie w ławce szkolnej. Kiedy już zdasz sobie sprawę, że szkoła w niczym ci nie pomoże, rodzice też nie mieli szansy cię wesprzeć, to zaczynasz kombinować, jak przetrwać. Za chwilę dostanę dyplom niezłej uczelni, ale tak sobie myślę, że o sprzedaży i marketingu dowiedziałem się więcej w mojej firmie niż na uczelni. Kompetencje tak naprawdę budujesz w oparciu o to co robisz, a nie o to czego wysłuchasz na wykładach. Profesorowie już nie nadążają za tym, jak wszystko się zmienia, wykładają ze swoich karteczek, albo klikają slajdy, jakby nie zdawali sobie sprawy z tego, co za oknem. Czasem coś przedyskutujemy, ale to jałowa dyskusja. Jak zorganizowałem koło wsparcia dla kolegów, którzy nie zdali egzaminu, to dopiero się okazało, jak dużo możemy się od siebie nauczyć, jak potrafimy się spierać i skąd to wszystko wiemy. Na pewno nie ze szkoły! (Jurgiel-Aleksander, 2013)

Kiedy czegoś nie wiesz, klikasz w internecie i znajdujesz. Nie musisz znać jego historii. To tak jak w pracy, nie wiesz, jak wykonać zdanie, to pytasz kogoś doświadczonego i już, przecież nie studiujesz historii firmy, tylko szukasz, kto umie to zrobić. Ja zazwyczaj dzwonię do kolegów i rozwiązanie problemu mam w kilka minut. I tak powinno być w szkole, to znaczy problem i jak go rozwiązać, a nie jakieś wydumane teorie, historia ludzkości i jakieś abstrakcje. (Jurgiel-Aleksander, 2013)

Nieadekwatność edukacji do oczekiwań dorosłych zbudowana została w języku roszczeń i wokół niekorzystnej dla szkoły, a zwłaszcza dla uczelni oceny jakości uprawianej w niej dydaktyki oraz jakości realizowanych programów. Język obecnej tu krytyki, to język roszczeń wobec instytucji, ale też język zgody na podporządkowanie się sytuacji bycia uczniem, a nie poczucia konieczności wpływu na budowanie tej roli. Można by powiedzieć, że dorośli, krytykując edukację jako nieadekwatną do ich świata życia, uprawiają adaptacyjny rodzaj krytyki szkoły, żądając, by w miejsce starego uniwersytetu pojawił się nowy, tyle że „bardziej praktyczny”. W tym przypadku oznacza to, że ma być zorientowany na kształtowanie umiejętności potrzebnych w ich codziennym życiu: jak założyć firmę, jak rozmawiać z klientem, jak wychować dzieci, jak skutecznie wykorzystać program komputerowy do komunikowania się z klientem itd. Odejście od dydaktyki przyswajania treści na rzecz ich redukowania i przekształcania w taki sposób, by regulowały dostosowanie się do świata, stanowi podstawę naprawy szkoły. Jednocześnie jest dowodem w sprawie użyteczności uczenia się, które sprawdza się w świecie pozaszkolnym, stając się przesłanką traktowania dodatkowych źródeł wiedzy jako zastępczych wobec szkoły, a jednocześnie zdaniem badanych ważnych, bo aktualnych w dzisiejszym świecie. 
Można by powiedzieć, że kategoria opisu doświadczenia edukacyjnego ujawnia z całą mocą napięcie między nienowoczesnym wizerunkiem szkoły jako instytucji nienadążającej za zmieniającą się rzeczywistością a oczekiwaniem, że powinna ona wyprzedzać rozwój społeczno-ekonomiczny, dbając w ten sposób o swoich uczniów, o ich potencjał kwalifikacyjny. Racjonalizowanie doświadczeń pozaszkolnych z jednej strony ma podnosić wartość uczenia się społecznego i pozaszkolnego, z drugiej - akcentować nieekonomiczność funkcjonowania szkoły jako instytucji edukacyjnej (bo można w kilka minut dowiedzieć się tego samego z Internetu albo od kolegów), a zwłaszcza jej odporność na przekształcenia w sytuacji zmieniającego się rynku kwalifikacji.

Koncepcja doświadczenia edukacyjnego jako konsekwencja niedoświadczania edukacji adekwatnej do oczekiwań na każdym etapie kształcenia opiera się na krytyce dydaktyki w warstwie dotyczącej treści kształcenia i sposobu ich przetwarzania, ale także na przekonaniu, że kluczem do sukcesu jest kształtowanie praktycznych umiejętności przez człowieka. To oznacza, że jeśli szkoła nigdy nie spełniała oczekiwań badanych w tym zakresie, to należy ich poszukiwać w pozaszkolnych środowiskach. W tym sensie świat pozaszkolny jest źródłem wiedzy praktycznej, ale także kształtuje umiejętności praktyczne, rekompensując to, czego szkoła nie jest w stanie ukształtować.

Trudno jednocześnie nie zauważyć, że budowaniu przekonania o znaczeniu doświadczenia edukacyjnego wytworzonego poza szkołą jako adekwatnego do rzeczywistych potrzeb prawdziwego świata, towarzyszy przyznanie sobie jako dorosłemu statusu wszechwiedzącego podmiotu, który nie tylko wie, jakiej wiedzy i umiejętności potrzebuje, ale także, do jakiego świata należy się dostosować. Tak jakby uczenie się można by zredukować do wytworzenia nowej linii produkcyjnej, tym razem adekwatnej, bo dostarczającej lepszych narzędzi adaptacyjnych, których skuteczność została zagwarantowana przez samo miejsce produkcji, a nie ich rzeczywistą przydatność.

\section{Doświadczanie edukacyjne jako bycie w sytuacji wymiany zasobów (C)}

Ta koncepcja doświadczenia edukacyjnego, a właściwie doświadczania edukacyjnego wyrasta z postrzegania uczenia się jako procesu, który polega na wymianie zasobów między ludźmi ze środowiskiem i w środowisku. Charakter tych zasobów jest różny i obejmuje zarówno intelekt, społeczne zaangażowanie, działania praktyczne, dobra materialne, a proces wymiany został oparty na rozumieniu własnego uczenia się jako procesu społecznego. Ten 
sposób rozumienia doświadczenia edukacyjnego został wytworzony na podstawie traktowania uczenia się jako wpisanego pomiędzy prywatny i publiczny świat życia jednostki oraz rozumienia wrażliwości poznawczej podmiotu jako organizującej sposób jego życia, którą można kształtować.

Traktowanie uczenia się jako wpisującego się pomiędzy prywatny i publiczny świat życia daje o sobie znać, kiedy w materiale jest mowa o:

a) o różnych środowiskach uczenia się, szkolnych i pozaszkolnych jako równie znaczących i wzajemnie na siebie oddziałujących. Wówczas problem „praktyczności uczenia się" sam się rozwiązuje, bo jest pochodną podejmowanych działań przez jednostkę, aktywnego uczenia się a nie celem samym w sobie. Wynika z procesu wymiany umiejętności kształtowanych w różnych środowiskach i dla różnych celów:

Cieszę się, że jestem dekoratorką wnętrz i studia mi w tym pomogły. Lubię robić to, co robię, i chyba to miara mojego sukcesu. Robić to, co lubisz, studiować to, co Cię interesuje. Wtedy nie ma się pretensji do uczelni, ale też ważne jest to, że potrafisz przełożyć wiedzę szkolną na użytkową. Ze mną tak jest. Spełniam życzenia klientów, znam trendy we wzornictwie i to pomaga. (Jurgiel-Aleksander, 2013)

Dużo daje praktyka i to że się nie poddajesz, tylko szukasz ludzi z doświadczeniem, wiedzą i uczysz się od nich, ale też masz coś innym do zaoferowania. Na uniwersytecie jest dużo takich wykładowców, od których się można nauczyć, poradzą, jak zapytasz. Ja ciągle pytałam, chodzę na konsultacje, czytam ile się da. Nauczyłam się, że sama muszę zadbać o siebie i tak robiłam. Moi koledzy siedzieli i czekali na cud i się nie stał! Nic samo się nie dzieje! A ja mam fajną pracę i cos potrafię. (Jurgiel-Aleksander, 2013)

b) o traktowaniu uczenia się w szkole, w tym także w uczelni jako aktywnego procesu, to znaczy wymagającego działania od dorosłego ucznia, z wyraźnym eksponowaniem wymiany wiedzy i doświadczeń jako istoty procesu uczenia się:

Jedną próbę składania papierów miałam, jak moje dziecko miało 2 lata, ale wtedy uznałam, że jeszcze za wcześnie, tak minęło 10 lat. Ze zdobywaniem doświadczeń jest jak z życiem, jak chcesz się uczyć, to nie zastanawiasz się gdzie, tylko garniesz do siebie i dajesz coś z siebie innym. Ja studiowałam, chodziłam na kursy, uczyłam się z kolegami i od nich. Jak szukałam pracy, to odbywałam przy okazji staże. Na tym polega dorosłość, że chcesz, że działasz, że się nie poddajesz i ja to robiłam. (Jurgiel-Aleksander, 2013) 
Aktywność w uczeniu się jest tu pochodną wrażliwości poznawczej, traktowanej bardziej jako kwestia wytwarzanych kulturowo kompetencji. Wrażliwość poznawcza, jak się okazuje, może być uaktywniona w procesie wymiany doświadczeń i to zarówno w sferze instytucjonalnie zorganizowanej edukacji, jak i innych praktyk uczenia się rozwijających moc sprawczą jednostki:

Kiedy przeprowadziłam się do Poznania, wiedziałam, jak trudno mi będzie i jak jednocześnie może być ciekawie znów poznawać nowych ludzi w pracy i na studiach. [...] Teraz razem podróżujemy, razem pracujemy, odkryłam pasję w fotografowaniu i chyba ją wykorzystam w pracy. Na studiach jest koło naukowe na dziennych, dołączyłam do nich. Okazało się, że umiem dużo rzeczy. Fajnie jest coś tworzyć. (Jurgiel-Aleksander, 2013)

To oznacza, że proces wymiany zasobów nie jest tylko procesem wpisanym w ekonomiczną wymianę dóbr obliczoną na przetrwanie w sytuacji rywalizacji i wolnego rynku, ale od początku kształtuje kondycję rozwijającego się podmiotu $z$ ukierunkowaniem na to, co tu i teraz. Nie jest to jednak kondycja, która ignoruje uprzednie doświadczenia w kształtowaniu rezultatów w uczeniu się, zwłaszcza gdy chodzi o siłę warunków, w jakich ten proces przebiega, ale jednocześnie pokazuje, że ich brak może być siłą sprawczą. W dużej mierze pozwala to dorosłemu nieustannie angażować się w pracę na rzecz własnej teraźniejszości i przyszłości, zwłaszcza jeśli te działania okazują się wbrew temu, co dotychczas oczywiste i praktykowane społecznie. Można by powiedzieć, że konstruujemy dorosłość na miarę własnych możliwości, niejako wiedząc, że jeśli chcemy coś w życiu osiągnąć, to skazani jesteśmy na bycie dojrzałymi. Z punktu widzenia analizowanych kontekstów w kształtowanie owej dojrzałości wpisuje się wychowanie dzieci, dbanie o małżeństwo, przeprowadzka, aktualnie organizowana pomoc sąsiedzka, nowa praca w dużym mieście, ale także dążenie do profesjonalizmu w zakresie realizacji roli zawodowej.

\section{Czego warto być świadomym, realizując projekt fenomenograficzny?}

Technicznie dochodzenie to tych trzech koncepcji odbywało się zgodnie z wymienionymi krokami. Jednocześnie ujawniło jak fenomenografia odkrywa skomplikowane relacje wewnątrz koncepcji, miesza uporządkowane 
konstrukcje, z którymi jako badacze już się oswoiliśmy i między którymi postawiliśmy linie demarkacyjne (np. edukacja teoretyczna vs. praktyczna, edukacja szkolna vs. uczenie się pozaszkolne itd.), szuka relacji między wydawałoby się nieprzystawalnymi światami. Potencjał opisanej kategorii leży w ręku badacza, który trzymając się ściśle kroków postepowania w pracy nad zarejestrowanym tekstem, jego dzieleniem na części, porządkowaniem, porównywaniem i ustalaniem jednorodnego kryterium, poszukuje klucze do „otwarcia drzwi” i uwolnienia idei, która jest w środku. Nie jest to zadanie łatwe, ponieważ nie zadawala się on podziałami świata na biały i czarny, ale właśnie dlatego, że karmi się jego „szarościami”, odkrywając dystynkcje. Przykładem owej szarości w prezentowanym tu projekcie jest krytyka szkoły jako instytucji obecna w pierwszej i drugiej koncepcji doświadczenia. Jak wynika $\mathrm{z}$ fragmentów wypowiedzi, została ona zbudowana na niezadowoleniu badanych z powodu tego, jakiej wiedzy dostarczają instytucje edukacyjne. Manifestowany przez badanych w tym miejscu problem nie polega tylko na szukaniu proporcji między tym, jakiej wiedzy oni potrzebują (a raczej nie potrzebują), a tym, na jakie umiejętności chcieliby położyć nacisk w swojej edukacji. Nie jest to wyłącznie kwestia tego, jak niezadawalającą dydaktykę zorientowaną na transmisję wiedzy zastąpić aktywizującymi metodami uczenia się, ale - jak zdają się mówić badani - jak instrumentalnie wykorzystać codzienność jako źródło wiedzy praktycznej i uczynić świat łatwym, nieskomplikowanym, łatwiejszym, by się do niego dopasować. W dalszym ciągu jest to zatem kwestia znaczenia adaptacyjnej funkcji edukacji i jej różnych odmian.

W tego typu projektach badani, opowiadając o własnym doświadczeniu, tym samym postrzeganiu świata, identyfikują go z codziennym funkcjonowaniem. Relacjonując „to, co jest”, nakładają doświadczenie na własne wyobrażenie zjawiska, które jednak zakotwiczone w kulturze nie pozwala wyjść poza obowiązujący schemat poznawczy. Przykładem owego nałożenia własnego wyobrażenia o świecie na doświadczenia w materiale jest koncepcja uczenia się rozumiana jako proces nabywania wiedzy polegający na zapamiętywaniu treści wynikających ze studiowanej dyscypliny i jej rozwoju obecna w pierwszej koncepcji doświadczenia edukacyjnego. Instrumentalnie rozumiane uczenie się, skoncentrowane na przyswajaniu wiedzy, pamięciowych technikach uczenia się, spełnianiu wymagań instytucji kształcącej jest tu odbierane przez badanych szerzej, bo jako model społecznego funkcjonowania człowieka w świecie, od którego wymaga się tego typu zachowania. $Z$ jednej strony osadzenie w studiowanej dyscyplinie ma zapewnić sukces w karierze zawodowej, z drugiej - umiejętność podporządkowywania się 
wymaganiom zapewnia sprawne funkcjonowanie w świecie pracy. To oznacza, że im więcej wiesz jako uczeń, tym lepszym będziesz pracownikiem, im bardziej starasz się nabyć potrzebną wiedzę, tym bardziej zasługujesz na awans. Ten rodzaj społecznego rozwoju wyraźnie zogniskowany wokół odtwarzania relacji podporządkowania i na funkcjonalnym urządzeniu społeczeństwa, w którym każdy ma przypisane miejsce, traktowany jest przez badanych jako najbardziej „oczywisty” i zgodny z oczekiwaną dydaktyką uprawianą w szkole i na uniwersytecie. Nie jest poddawany krytyce z powodu istoty, ale z powodu braku narzędzi do dostosowania się do niego. Dzięki zastosowanemu podejściu fenomenograficznemu udało się pokazać, odtwarzając praktyki edukacyjne, że w ich koncepcje wpisane jest społeczne na nie zapotrzebowanie. $Z$ jednej strony nie potrafimy sobie wyobrazić, że edukacja szkolna i uniwersytecka mogłyby inaczej wyglądać, a z drugiej próbujemy kształtować własny świat na miarę własnych możliwości - co odnajdujemy w ujawnionej koncepcji „doświadczenia edukacyjnego rozumianego jako procesu wymiany zasobów". Można powiedzieć optymistycznie, że ta ostatnia wskazuje na moc indywidualnego zaangażowania podmiotu w kształtowanie wrażliwości społecznej i poznawczej, ale w takim zakresie, w jakim znów ten sam „nasz”, kulturowy świat nam na to pozwoli.

\section{Bibliografia}

Brookfield S. D. (2005), The power of critical theory for adult learning and teaching, New York.

Dahglern L. O., Abrandt-Dahlgren M,. Hult H., Hard af Segerstad H., Szkudlarek T., Gajda M., Jurgiel A., Kopciewicz L., Marzec J., Męczkowska A., Mendel M. (2005), Conceptions of learning among teachers and students in higher education: a swedish-polish comparative study, [w:] T. Maliszewski, W. J. Wójtowicz, J. Żerko (red.), Anthology of social and behavioural sciences, Linköping.

Eklund-Myrskong G. (1998), Students' conceptions of learning in different educational contexts, „Higher Education”, nr 35.

Fox D. (1983), Personal theories of teaching, „Studies in Higher Education”, vol. 8, nr 2.

Franke A., Dahlgren L. O. (1996), Conceptions of mentoring: an empirical study of conceptions of mentoring during the school- based teacher education, „Teaching and Teacher Education", vol. 12, nr 6.

Hasselegren B., Beach D. (1997), Phenomenografhy: A good-for nothing brother of phenomenology?, „Higher Education Research and Development” 1997, vol. 16, nr 2. 
Jurgiel - Aleksander A. (2014), The mechanism of creating educational experience as the indicator of educational competence in the narrations of adult students. An excerpt from case study, "Edukacja Dorosłych", nr 1.

Jurgiel A. (2008), Doświadczanie dorosłości w byciu studentem. Fragment badania fenomenograficznego, „Dyskursy Młodych Andargogów”, nr 9.

Jurgiel A. (2011), Walka o zmianę statusu a (nie)moc kształcenia w świetle analizy doświadczeń edukacyjnych kobiet. Studium biograficzne, „Rocznik Andragogiczny”.

Jurgiel- Aleksander A. (2013), Doświadczenie edukacyjne w perspektywie andragogicznej. Studium biograficzno-fenomenograficzne, Gdańsk.

Jurgiel-Aleksander A. (2015), Jaka edukacja i dla kogo? Biografie edukacyjne dorostych i ich społeczny wymiar, „Rocznik Andragogiczny”.

Marton F. (1986), Phenomenography: A Research Approach to Investigating Different Understandings of Reality, „Journal of Thought” 1986, vol. 21, nr 3.

Marton F., Booth S. (1997), Learning and awarness, Mahwah, N. J.: Erlbaum Associates.

Męczkowska A. (2002), Od świadomości nauczyciela do konstrukcji świata społecznego. Nauczycielskie koncepcje wymagań dydaktycznych a problem rekonstrukcyjnej kompetencji ucznia, Kraków.

Nowicka M. (2010), Socjalizacja na lekcjach w klasach poczq̨tkowych. Praktyki-przestrzenie-konceptualizacje, Torun.

Richardson J. T. E. (1999), The concepts and methods of phenomenographic research, „Review of Educational Research” 1999, Vol. 69, No 1, p. 53-58.

Szkudlarek T. (1997), Poststrukturalizm a metodologia pedagogiki, „Socjologia Wychowania" t. 13, z. 317. 